\title{
Geochemistry and nature of protolith of quartz sillimanite schist from Sonapahar area, West Khasi Hills district of Meghalaya
}

\author{
V. Vanthangliana ${ }^{1 *}$, Jimmy Lalnunmawia $^{2}$, Laldinpuia $^{1}$, Lalhmingsangi $^{1}$ \\ ${ }^{1}$ Department of Geology, Pachhunga University College, Aizawl 796001, Mizoram, India \\ ${ }^{2}$ Department of Geology, Mizoram University, Tanhril 796004, Mizoram, India \\ Corresponding author: vantea_g@yahoo.com
}

\begin{abstract}
The Precambrian terrain of the Sonapahar area is characterised by the presence of a thin, long, discontinuous band of quartz-sillimanite schist which hosts the massive sillimanite-corundum deposits. The quartz sillimanite schists are generally siliceous, $\mathrm{SiO}_{2}(60.59-76.82 \mathrm{wt} \%)$ and are characterized by high $\mathrm{Al}_{2} \mathrm{O}_{3}$ content with average value (27.22 wt \%), low $\mathrm{P}_{2} \mathrm{O}_{5}, \mathrm{Fe}_{2} \mathrm{O}_{3}$ and $\mathrm{MgO}, \mathrm{MnO} \mathrm{Na}_{2} \mathrm{O}, \mathrm{K}_{2} \mathrm{O}$ and $\mathrm{TiO}_{2}$. Average $\mathrm{MgO}, \mathrm{CaO}, \mathrm{K}_{2} \mathrm{O}$ and $\mathrm{Na}_{2} \mathrm{O}$ values are generally less than 0.15 wt $\%$. $\mathrm{TiO}_{2}$ values range from $0.13-0.35$ wt $\%$. Compared with the post-Archean metasediments, the Sonapahar schists are richer in $\mathrm{SiO}_{2}$ and $\mathrm{Al}_{2} \mathrm{O}_{3}$ but depleted in other oxides. In Harkers variation diagram, $\mathrm{SiO}_{2}$ shows a linear inverse correlation with $\mathrm{Al}_{2} \mathrm{O}_{3}$ and $\mathrm{TiO}_{2}$, but there are no significant correlations observed with other oxides. In general, $\mathrm{Al}_{2} \mathrm{O}_{3}$ and $\mathrm{SiO}_{2}$ constitute more than 97 wt \% in most of the samples. Among trace elements, $\mathrm{Zr}, \mathrm{Hf}$ and $\mathrm{Pb}$ are characterized by high concentration and low $\mathrm{La} / \mathrm{Th}$ and $\mathrm{Th} / \mathrm{U}$. The schistose rocks are generally low in $\mathrm{Sr} / \mathrm{Ba}$ ratios $(<0.88 \%)$ and relatively high content of $\mathbf{R b}$ in contrast to $\mathrm{Ba}$. Chondrite normalize REE patterns of the schists reveals a strongly fractionated patterns with enriched LREE and low HREE values $[(\mathrm{La} / \mathrm{Yb}) \mathrm{N}=\mathbf{2 7 . 3 8 - 4 3 . 9 8 ]}$ with prominent negative Eu-anomaly. The concentration of $V$ (10.28-51.49) shows the apparent mobility in these quartz sillimanite schists and the oxidizing conditions prevailed during weathering. Geochemical characteristics suggested that quartz sillimanite schists from Sonapahar area are derived from post-Archean recycled upper crust sources and the precursor sediments are possibly derived from felsic rocks and probably not mafic rocks.
\end{abstract}

Keywords: Quartz sillimanite schists, Sonapahar, geochemistry, sediment, rock.

\section{INTRODUCTION}

Precambrian basement of the Shillong plateau in Meghalaya, India, is characterised by high grade gneisses which are intruded by basic and ultrabasic rocks of different ages. In Sonapahar area, cordierite bearing granulitic gneisses, basic granulites and quartz sillimanite schists were largely exposed. The Shillong plateau, elsewhere considered a detached Precambrian block of Indian Peninsula in the northeast India is bounded to the south east by E-W trending Dauki fault (Figure 1), to the north by Brahmaputra fault1 or Oldham fault (Bilham and England, 2001) to the west by the broadly NNE-SSW Indo-
Myanmar belt. The plateau is separated from Mikir Hills in the northeast by the alluvium tract of the Kopili fault system (Dasgupta and Nandy, 1982). The demonstrable recognition of Mesoproterozoic granulites in the Shillong Meghalaya Gneissic Complex (SMGC) is new and their similarity with temporally related rocks elsewhere in the Indian shield indicates that the Shillong Plateau has been a part of the Indian shield since the Mesoproterozoic.

Chatterjee et al. (2007) suggested that the PanAfrican suture passing through Prydz Bay in Antarctica possibly continued northward into India through the SMGC with the western margin of the suture between the Sonapahar and the Garo-Goalpara Hills regions. The geology of the Shillong plateau is very complex, as the 


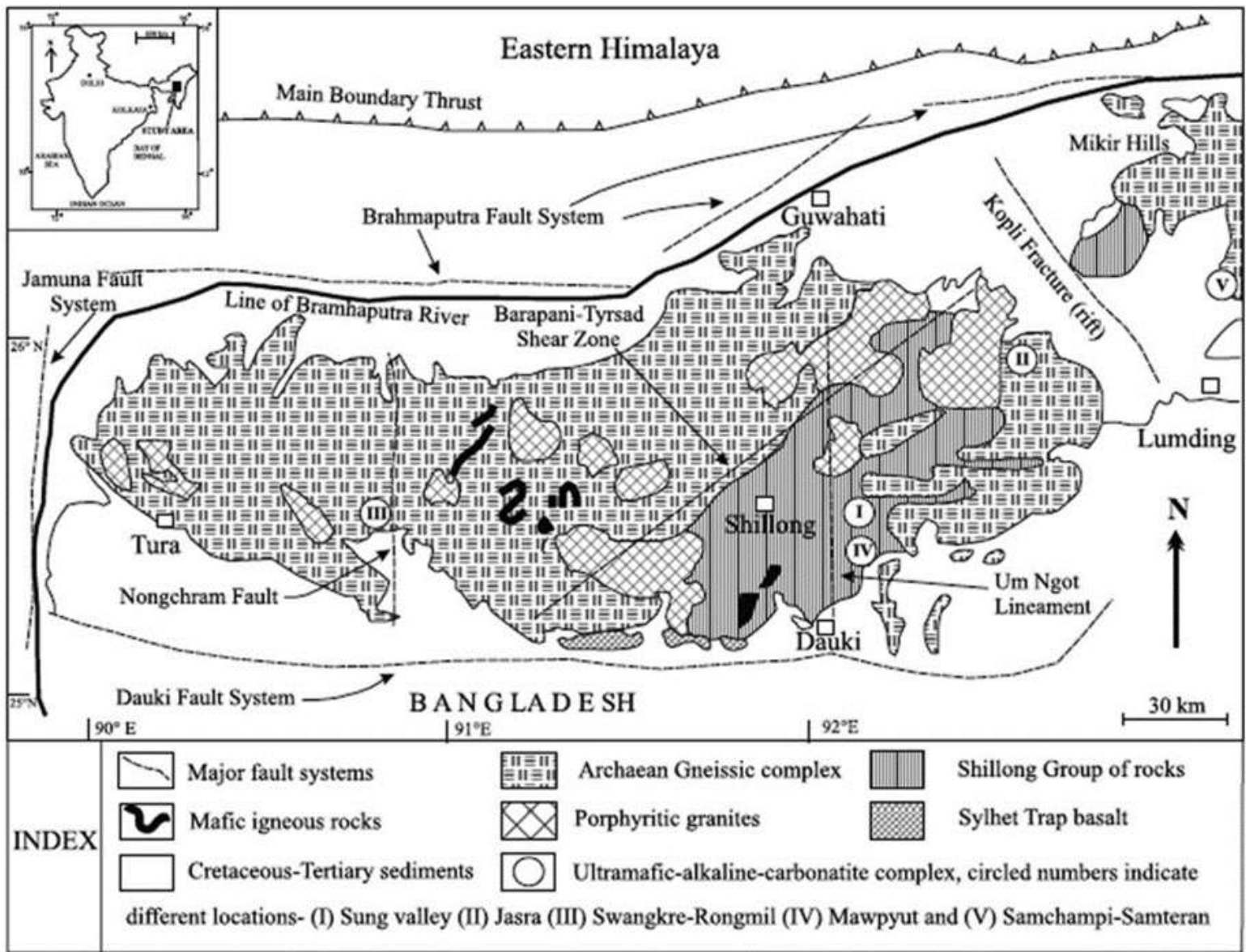

Figure 1: Regional geological and tectonic framework of the Shillong Plateau (after Srivastava and Sinha, 2004).

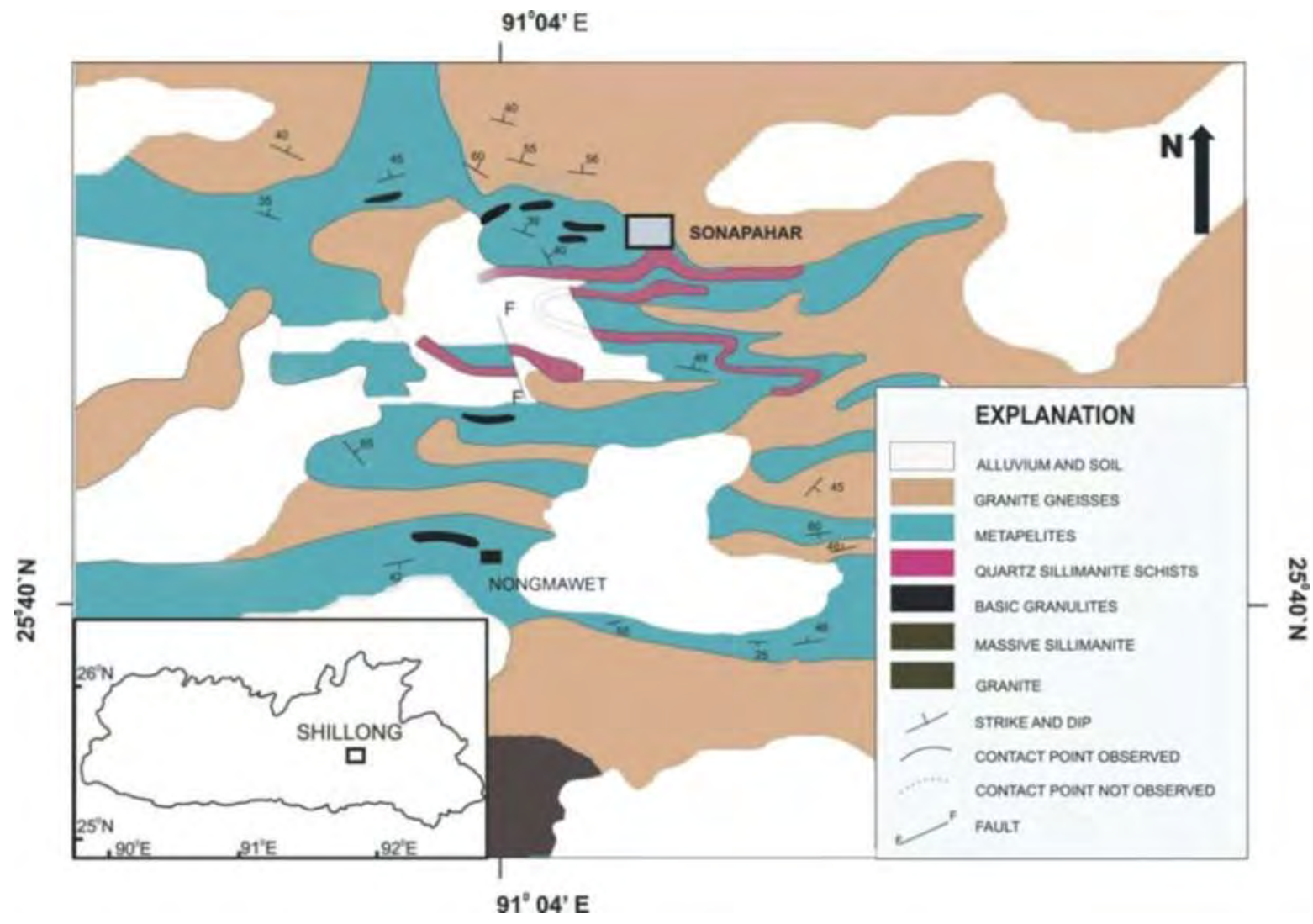

Figure 2: Geological and sample location map of the study area. 
plateau represents a checkered history of evolution with contrasting petrological units of different ages, consisting of gneisses, metasedimentary supracrustals, granitoids, mafic dykes, alkaline and carbonate rocks and Trap rocks. Rocks of upper amphibolite to granulite facies, flanked on the east by greenshists facies rocks belonging to the Shillong Series of Precambrian age and to the south by sedimentary rocks and basic volcanics of cretaceous age are present (Lal et al., 1978). The area is dominated by blastoporphyritic granite and granite gneisses intrusive into the basement gneisses. Cordierite-garnet-biotitesillimanite gneisses interlayered with quartz-sillimanite schists, non-garnetiferous mafic granulites and rare calc silicate gneisses occur as distended bands and lenses within the granites (Lal et al., 1978).

Composition of rocks and their source rocks are efficiently studied by analysis of the major oxides, rare earth element (REE) concentrations and other trace elements; because trace elements, including REE, are weakly fractionated in the processes of sedimentation and metamorphism, so that the rocks even when metamorphosed to high pressures of the granulite facies retain their geochemical signatures inherited from the source rocks (Cox et al., 1995). It is reasonable to believe that shales and the products of their metamorphism are indicators of the composition of the continental crust in terms of the behavior of trace elements and the geochemical record of these rocks makes it possible to trace the evolution of this crust (Taylor and Mclennan, 1985).

The Precambrian terrain of the Sonapahar area is characterised by the presence of a thin, long, discontinuous band of quartz-sillimanite schist which hosts the massive sillimanite-corundum deposits (Figure 2). The massive sillimanite-corundum occurs as randomly distributed bodies of variable size and shape within the quartzsillimanite schist. Quartz sillimanite schists are mostly exposed near the Sonapahar town. These rocks exhibit a well-developed foliation defined by alternate bands rich in quartz and sillimanite, at places with corundum. The quartz-sillimanite schists are highly crumpled at places, due to intense puckering and incipient axial fractures. They are mainly composed of sillimanite and quartz with accessory biotite. This study is an attempt to exemplify the nature of protolith of quartz sillimanite schists base on the petrography and a major and trace element which constitute an important rock unit of the area.

\section{MATERIALS AND MethodS}

For microscopic studies, thin sections were prepared at the Department of Geology, Kumaun University, Nainital, and preparation of some slides and detailed petrographic studies were done at the Department of Geology, Mizoram University, using Leica DMEP trinocular model. For geochemical analysis, samples were pulverized using an agate mortar at NGRI, Hyderabad. Major elements were analysed by XRF (Philips MagiX PRO PW
2440 wavelength dispersive X-ray fluorescence spectrometer with automatic sample changer PW 2540). For the dissolution of samples for analysis of trace element and rare earth element (REE) by ICP-MS, a Perkin Elmer SCIEX (ELAN DRC II ICP mass spectrometer, Toronto, Canada) was used. During analysis, natural standards, viz. JG2, AG-2 and SDC-1 were also analyzed simultaneously to check the precision and accuracy of analytical data. The procedures followed in the preparation of the rock samples for analyses on XRF and ICP-MS were of national and international standards (Roy et al., 2007).

\section{RESULTS}

\section{Petrography}

The quartz sillimanite schists are fine to mediumgrained, display well defined schistosity and contain quartz, sillimanite, biotite with accessory rutile and zircon. The mineral associations identified are: a) quartz sillimanite - biotite \pm Ru tile \pm zircon and b) quartz - sillimanite - biotite $\pm \mathrm{K}$ - feldspar. Quartz occurred as polycrystalline aggregates defining foliation, but some are randomly oriented crystals. In general, quartz grains show uniform twinning, but some grains exhibit wavy extinction (Figure 3A). Two generations of quartz are evident. The first one is coarser grained, usually anhedral and elongated parallel to the fabric. The finer grained variety occurs as localized granoblastic aggregates and show uniform extinction. This variety may likely be of secondary origin. Sillimanite commonly occurs as radiating needles, acicular and sometimes prismatic crystals. It is the major constituents of the assemblages. Sillimanites are oriented sub parallel to the principal foliation. In some cases, sillimanites are intergrowth with biotite. Biotites are less dominant mineral in quartz sillimanite schists. It occurs as flakes, which are sometimes feebly deformed (Figure 3B). It shows high order interference colour. It is pleochroic from pale yellowish to brownish yellow. Flakes of biotite along with sillimanite are oriented parallel to schistosity. Biotites are most commonly associated with flattened grains of quartz.

\section{Major oxides}

The quartz sillimanite schists are generally siliceous, $\mathrm{SiO}_{2}$ (60.59-76.82 wt \%) and are characterized by high $\mathrm{Al}_{2} \mathrm{O}_{3}$ content with average value (27.22 wt \%), low $\mathrm{P}_{2} \mathrm{O}_{5}$, $\mathrm{Fe}_{2} \mathrm{O}_{3}$ and $\mathrm{MgO}, \mathrm{MnO}, \mathrm{Na}_{2} \mathrm{O}, \mathrm{K}_{2} \mathrm{O}$ and $\mathrm{TiO}_{2}$. The values are however within the range for metasediments (Weaver, 1989). Average $\mathrm{MgO}, \mathrm{CaO}, \mathrm{K}_{2} \mathrm{O}$ and $\mathrm{Na}_{2} \mathrm{O}$ values are generally less than 0.15 wt \%. $\mathrm{TiO}_{2}$ values range from 0.13 0.35 wt \%. Compared with the post Archean metasediments, the Sonapahar schists are richer in $\mathrm{SiO}_{2}$ and $\mathrm{Al}_{2} \mathrm{O}_{3}$ while depleted in other oxides. In general, $\mathrm{Al}_{2} \mathrm{O}_{3}$ and $\mathrm{SiO}_{2}$ constitute more than $97 \mathrm{wt} \%$ in most of the samples. In 

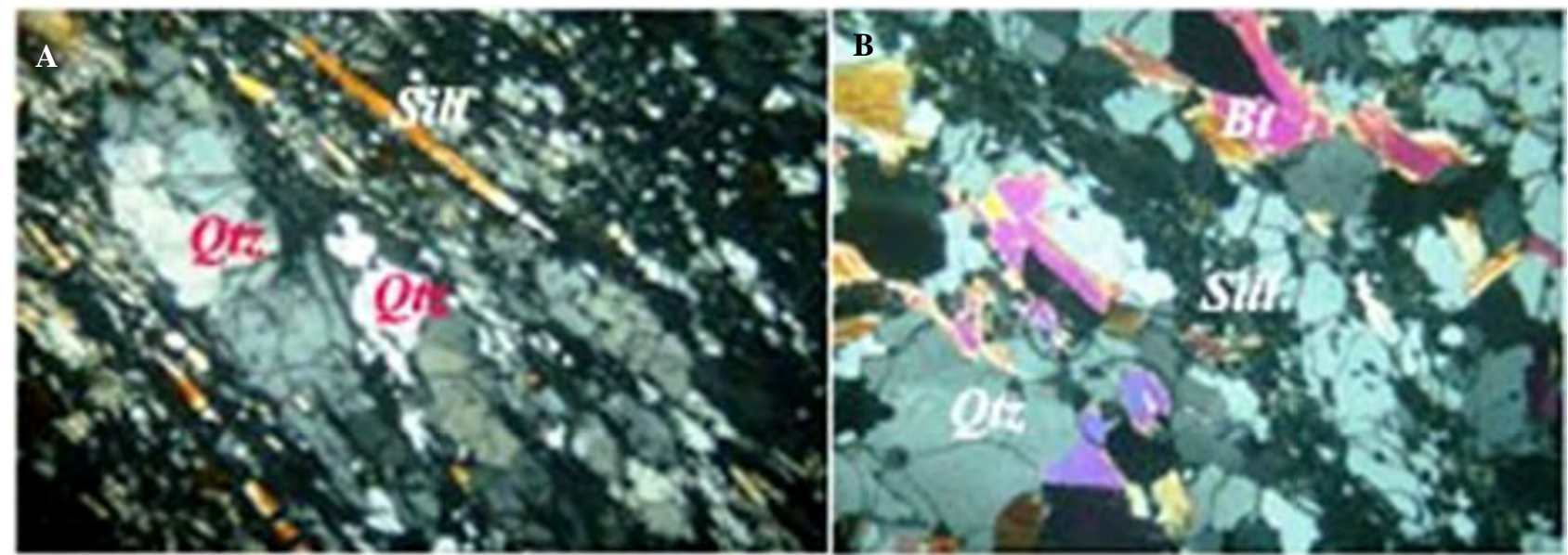

Figure 3: A. Polycrystalline quartz (Qtz) and needle sillimanite (Sill) defining foliation in quartz sillimanite schists (under crossed nicols). B. Mineral association of sillimanite (Sill), quartz (Qtz) and biotite (Bt) in quartz sillimanite schists (under crossed nicols).
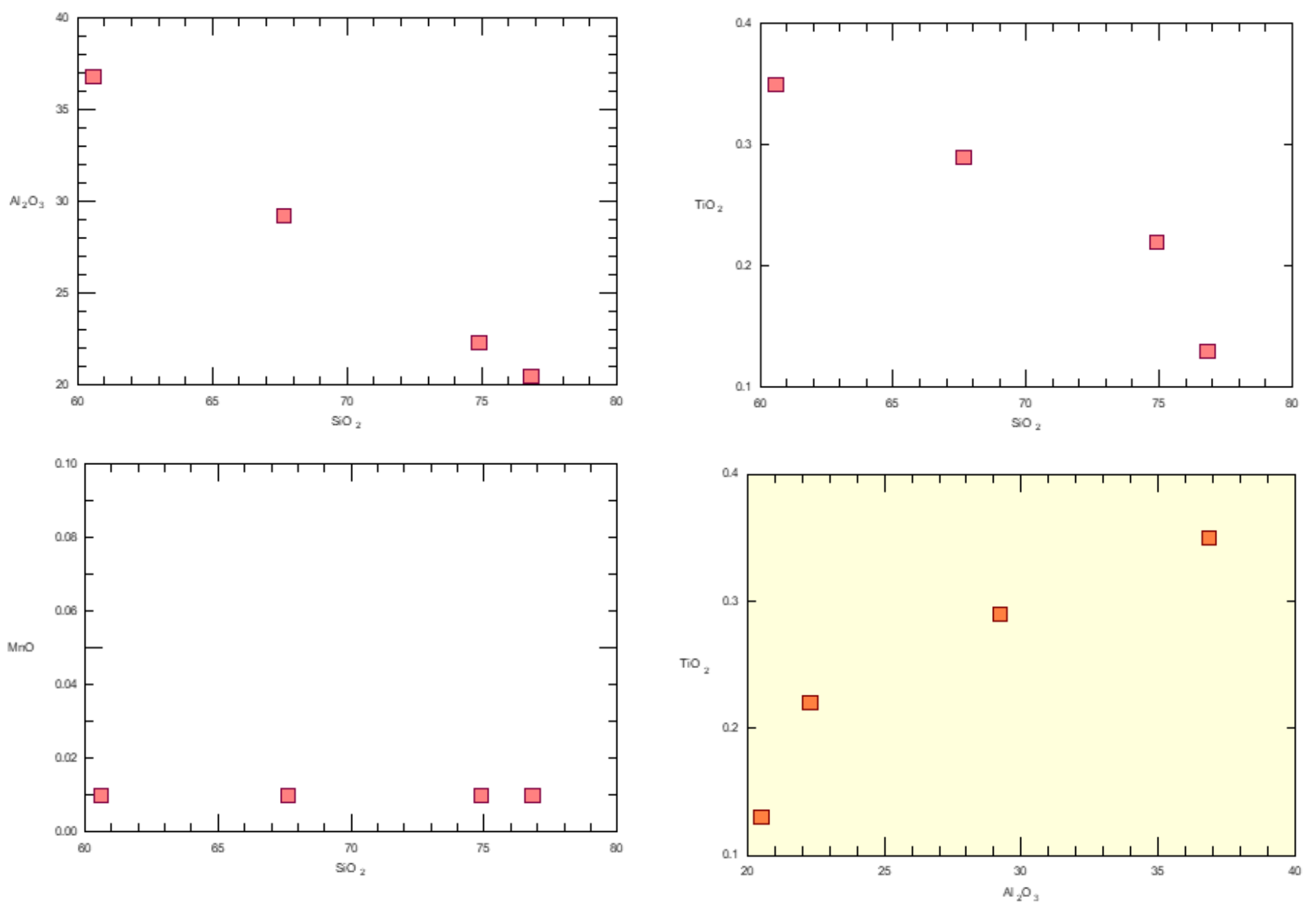

Figure 4: Harker's variation diagram for major oxides of quartz sillimanite schists of the Sonapahar area, Shilong plateau. 
Figure 5: REE patterns of quartz sillimanite schists from the Sonapahar area, Meghalaya (normalizing values are after Sun and McDonough, 1989).

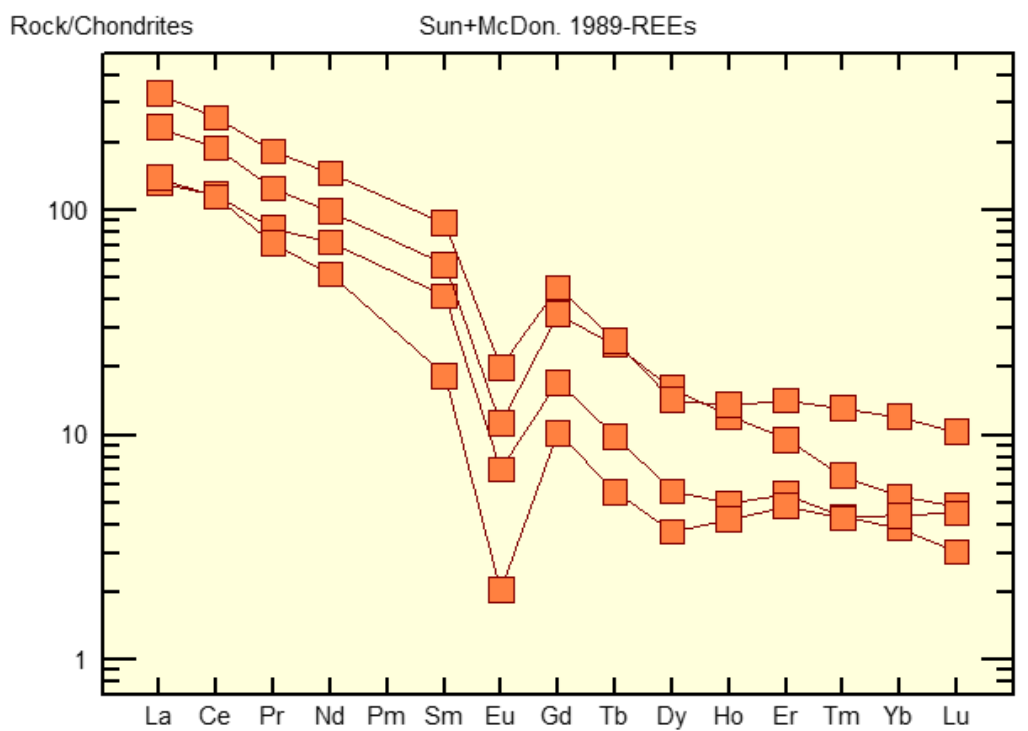

Figure 6: Spider diagram for the elements of the quartz-sillimanite schists normalised to PAAS (Post-Archaean Australian Shale; McLennan 1989). The elements are in succession with decreasing ionic potential towards the right.

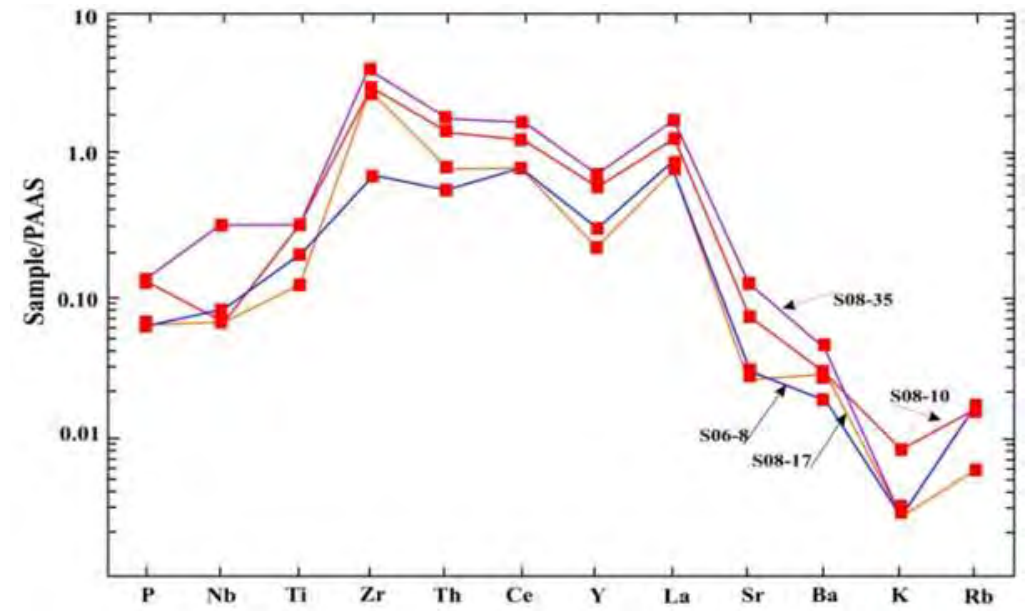

Harkers variation diagram, $\mathrm{SiO}_{2}$ shows a linear inverse correlation with $\mathrm{Al}_{2} \mathrm{O}_{3}$ and $\mathrm{TiO}_{2}$, but there are no significant correlations observed with other oxides. This may be due to limited number of samples. However, a strong positive correlation is also observed between $\mathrm{Al}_{2} \mathrm{O}_{3}$ and $\mathrm{TiO}_{2}$ (Figure 4).

\section{Trace elements}

Among trace elements, $\mathrm{Zr}, \mathrm{Hf}$ and $\mathrm{Pb}$ are characterized by high concentration relative to other. In particular, the high $\mathrm{Zr}$ content may reflect the presence of detrital zircon in the rocks (Elueze, 1981). $\mathrm{Zn}, \mathrm{Cu}$ and Co content is generally low. The schistose rocks are generally low in $\mathrm{Sr} / \mathrm{Ba}$ ratios $(<0.88 \%)$. The relatively high content of $\mathrm{Rb}$ in contrast to $\mathrm{Ba}$ indicates the contribution of felsic components can be rule out since $\mathrm{Ba}$ indicates $\mathrm{K}$-feldspar-rich source rocks (Okonkwo, 1992; Okonkwo and Winchester, 1998). All the LILEs, e.g. Rb, K, and Ba are characterized by low concentration.

Most of the samples analysed have low La/Th and Th/ $\mathrm{U}$. This feature is normally associated with post Archean recycled upper crust sources (Leyleroup et al., 1977; Taylor et al., 1986). $\mathrm{V}$ is known to be mobile under oxidising weathering conditions (Rye and Holland, 2000a). The concentration of $\mathrm{V}(10.28-51.49)$ suggests the apparent mobility in these quartz sillimanite schists and may indicate that oxidizing conditions prevailed during weathering.

\section{Rare earth elements}

Chondrite normalize REE patterns of the schists reveals a strongly fractionated patterns with enriched LREE and low HREE values $\left[(\mathrm{La} / \mathrm{Yb})_{\mathrm{N}}=27.38-43.98\right]$ (Figure 5). The REE patterns was characterized by prominent negative Eu-anomaly, $\mathrm{Eu} / \mathrm{Eu}^{*}=0.14-0.29$. Despite the limited data set, different levels of the $\Sigma$ REE have been observed.

\section{DISCUSSION}

For the quartz sillimanite schists, both the granite gneisses and metapelites are the older rocks and were possible sources for precursor sediments of the schists. 
The high $\mathrm{CIA}$ and $\mathrm{CIW}$ values indicate that the sillimanite schists might have been derived from both metapelites with larger proportions and granite gneisses in smaller proportions. The quartz fractions might have been derived from more granite gneisses and clay fraction most likely derived from the metapelites. The $\mathrm{Nb}$ content of the schists is extremely low compared to PAAS in the range of $1.3 \mathrm{ppm}$ to $6 \mathrm{ppm}$ (average 2,5 ppm). Since $\mathrm{Nb}$ substitutes for $\mathrm{Zr}$ in zircon, the elevated concentration of $\mathrm{Zr}$ in the schists can therefore account for the substitution of $\mathrm{Nb}$ for $\mathrm{Zr}$. Both the rock suites have higher thorium (Th) cerium and (Ce) values than the PAAS. Ce is the main element in monazite, a highly resistant mineral that is chiefly derived from the weathering of granites and granite pegmatites and therefore suggests the precursor sediments are possibly derived from felsic rocks and probably not mafic rocks.

The quartz sillimanite schists have positive $\mathrm{Ba}$ anomalies. Potassium is commonly adsorbed to clay minerals under suitable conditions. Pettijohn (1975) estimated that Precambrian and Palaeozoic shales contained an average of $3.2 \% \mathrm{~K}_{2} \mathrm{O}$ and $1.1 \% \mathrm{Na}_{2} \mathrm{O}$; close to Condie's (1993) calculated averages for Proterozoic shales of $3.62 \% \mathrm{~K}_{2} \mathrm{O}$ and $1.06 \% \mathrm{Na}_{2} \mathrm{O}$ compared to $3.7 \% \mathrm{~K}_{2} \mathrm{O}$ and $1.2 \% \mathrm{Na}_{2} \mathrm{O}$ in PAAS. In primitive Precambrian paleosoil, $\mathrm{K}$ was mainly derived from the weathering of $\mathrm{K}$-feldspar and/or muscovite and fixed in illite, whereas $\mathrm{Ca}$ and $\mathrm{Mg}$ were dissolved and removed from the sediments.

The high values for $\mathrm{Zr}$, Th, Ce and La suggest that the precursors to the quartz-sillimanite Schists were probably sand-clay mixtures with zircon enrichment in the sand fraction (Figure 6). The major element geochemistry rules out some other possible models of origin for the sillimanite schists. Immature sediments, such as glacial clay or loess, can be excluded because the high CIA index suggests rather highly weathered sediments derived in a warm, humid climate. The quartz-sillimanite schists cannot be simple metamorphic derivatives of bauxite deposits, as bauxites normally contain more than $40 \% \mathrm{Al}_{2} \mathrm{O}_{3}$, which is well above the level for the sillimanite schists. Pelagic red clays can also be excluded since they have different element distributions than the sillimanite rocks (McLennan et al., 1990; Li, 1991, 2000). Even if the protolith and paleoenvironmental condition for the precursor sediments of the sillimanite-bearing schists remains somewhat elusive, there seems to be ample support for the notion that clay-rich sedimentary precursors for the gneisses and sandy-clay mixture for the schists developed during weathering in a warm, humid environment.

Chondrite normalize REE concentrations show variable LREE/HREE ratios $\left[(\mathrm{La} / \mathrm{Yb})_{\mathrm{N}}=27.38-43.98\right]$. When compared with the patterns of the granite gneisses, the rare earth elemental patterns of the quartz-sillimanite schists show a remarkable similarity. From the field relationships with the granite gneisses which hosting the other rock units, it is reasonable to assume that the quartz-sillimanite schists were derived from granite gneisses.

\section{CONCLUSION}

High CIA index of quartz sillimanite schists suggests rather highly weathered precursor sediments derived in a warm and humid climate. Geochemical characteristics shows that quartz sillimanite schists from Sonapahar area are sourced from post Archean recycled upper crust and the precursor sediments are possibly derived from felsic rocks and probably not mafic rocks. A very conformable trend of REE plot for quartz sillimanite schists suggest a singular source for its precursor sediments.

\section{REFERENCES}

Bilham, R., England, P. (2001). Plateau 'pop-up' in the great Assam earthquake. Nature, 410, 806-809.

Chatterjee, N., Mazumder, A.C., Battacharya, A., Saikia, R.R. (2007). Mesoproterozoic granulites of the Shillong - Meghalaya Plateau: Evidence of westward continuation of the Prydz Bay Pan-African suture into Northeastern India. Precambrian Res, 152, 1-26.

Condie, K. C. (1993). Chemical composition and evolution of the upper continental crust: Contrasting results from surface samples and shales. Chem. Geol, 104: 137.

Cox, R., Lowe, D.R., Cullers, R.L. (1995). The influence of sediment recycling and basement composition on evolution of mudrock chemistry in the South Western United States. Geochim Cosmochim Acta, 59, 29192940.

Dasgupta, S., Nandy, D.R. (1982). Seismicity and tectonics of Meghalaya Plateau, North-eastern India. In: Proceedings of the Symposium on Earthquake Engineering. University of Roorkee, pp. 19-24.

Elueze, A. A. (1981). Dynamic metamorphism and oxidation of amphibolites, Tegina area, north western $\mathrm{Ni}$ geria. Precamb. Res, 14: 368-379.

Lal, R.K., Ackermand, D., Seifert, F., Haldar, S.K. (1978). Chemographic relationships in sapphirine-bearing rocks from Sonapahar, Assam, India. Contrib Mineral Petrol, 67, 169-187.

Leyleroup, A., Dupy, C., Andrian-mbolona, R. (1977). Chemical Composition and consequence of evolution of the French Massive Central Precambrian crust. Mineral Petrol, 62, 283-300.

Li, Y.-H. (1991). Distribution patterns of the elements in the ocean: A synthesis. Geochimica et Cosmochimica Acta 55, 3223-3240.

Li, Y.-H. (2000). A Compendium of Geochemistry. New Jersey: Princeton University Press, p. 475.

McLennan, S.M. (1989). Rare earth elements in sedimentary rocks: influence of provenance and sedimentary processes. Geochemistry and Mineralogy of Rare Earth Elements, 21, 169-200. 
McLennan, S.M., Taylor, S.R., McCulock, M.T., Maynard, J.B. (1990). Geochemical and Nd-Sr isotopic composition of deep sea turbidites: Crustal evolution and plate tectonic associations. Geochim. Cosmochim .Acta, 54, 2015-2050.

Okonkwo, C.T. (1992). Structural geology of basement rocks of Jebba area, Nigeria. Journal of Mining and Geology, 28, 203-209.

Okonkwo, C.T., Winchester, J.A. (1998). Petrochemisry and petrogenesis of migmatitic gneisses and metagreywackes in Jebba area southwestern Nigeria. Journal of Mining and Geology, 36, 1-8.

Pettijohn, T. J. (1975). Sedimentary Rocks. New York: Harper and brothers, p. 718.

Roy, P., Balaram, V., Kumar, A. (2007). New REE and trace element data on two kimberlitic reference materials by ICP-MS. Geostand Geoanal Res, 31, 261-273.
Srivastava, R.K., Sinha, A.K. (2004). Geochemistry of Early Cretaceous alkaline ultramafic-mafic complex from Jasra, Karbi Anglong, Shillong Plateau, Northeastern India. Gond Res, 7, 549-561.

Sun, S.S., McDonough, W.F. (1989). Chemical and isotopic systematic of oceanic basalts: implication for mantle composition and processes. In: Saunders, A.D., Norry, M.J. (eds), Magmatism in the Ocean Basins. Geological Society of London Special Publications, 42: 313-345.

Taylor, S.R., Mclennan, S.M. (1985). The Continental Crust: Its Composition and Evolution. Oxford: Blackwell Scientific Publications, pp. 312.

Weaver, C. E. (1989). Clays, Muds and Shales. Amsterdam: Elsevier, p. 820. 